\title{
Assessment of Fluoride Content in Ground and Surface Water and its Environmental Impacts at Basavan-Bagewadi and Muddebihal Taluka of Bijapur District, Karnataka, India
}

\author{
M. S. YADAWE*, SMT D. M. HIREMATH and S. A. PATIL ${ }^{\S}$ \\ S.B.Arts and K.C.P.Sc.College Bijapur, Karnataka-586103, India.. \\ ${ }^{\S}$ Department of Chemistry, \\ Karnataka University Dharawad-580003, Karnataka, India. \\ mallikarjun_yadawe@yahoo.com
}

Received 23 July 2009; Accepted 15 September 2009

\begin{abstract}
An investigation was undertaken in 10 villages (28 samples) of Basavan-Bagewadi taluka and 11 villages (38 samples) of Muddebihal taluka of Bijapur district to assess fluoride and other physicochemical parameters. And also to assess the clinical symptoms like dental and skeletal fluorosis, joint pains and gastrointestinal diseases and to find out the severity of the disease. A check list developed with the help of available literature and in consolation with nutritionists was used to record clinical symptoms. A sample survey was made after examination for both sexes between the age of 8-50 years at BasavanBagewadi and Muddebihal taluka. Fluoride content varies from 0.40-6.40 mg/L and $1.10-7.10 \mathrm{mg} / \mathrm{L}$. However 12 samples were within the range, while 16 samples were above the permissible limits at Basavan-Bagewadi Taluka where as in Muddebihal taluka all the values are above the permissible limits of WHO respectively. The results show that, out of the 2992 examined 824 (25.89\%) people have dental and skeletal fluorosis, $274(9.15 \%)$ people have joint pains, $167(5.58 \%)$ have gastrointestinal discomfort and excessive thirst at different stages in Basavan-Bagewadi taluka. Among 2696 examined, 812(29.49\%) people had dental and skeletal fluorosis, $432(16.18 \%)$ people had joint pains, $415(15.54 \%)$ people had gastrointestinal discomfort and excessive thirst at Muddebihal taluka of Bijapur district.
\end{abstract}

Keywords: Fluoride, Clinical symptoms, Dental and skeletal fluorosis, Gastrointestinal discomfort.

\section{Introduction}

Fluorosis is an endemic disease resulting from excess intake of fluoride either through drinking water, food or dentifrices at concentration of $2.00 \mathrm{ppm}$ or above. Fluorosis of 
teeth has been reported to affect dental enamel. Chronic fluorine intoxication through drinking water containing above $10 \mathrm{ppm}$ of fluorine results in pathological changes of bone leading to skeletal fluorosis ${ }^{1}$. While the dental fluorosis can be easily recognized, the skeletal involvement is not clinically obvious until the advanced stage of crippling is reached. Water is the medium of intake by humans ${ }^{2}$. Fluoride can rapidly cross the cell membrane and is distributed in skeletal and cardiac muscle, liver, $\operatorname{skin}^{3}$ and erythrocytes ${ }^{4}$. Fluorosis is a major public health problem resulting from long term consumption of water with high fluoride levels. It is characterized by dental mottling and skeletal manifestations such as crippling deformities, osteoporosis and osteosclerosis clinical symptoms of dental and skeletal fluorosis in Gadag and Bagalkot districts of Karnataka is reported ${ }^{5}$.

In India, as many as 15 states are affected by endemic fluorosis and an extensive belt of high fluoride in water and soil is reported in south India ${ }^{6-9}$. Gulbarga district of Karnataka was found to be a fluorosis endemic are ${ }^{10-11}$. The documentation of clinical symptoms depicts the severity of the disorder and helps to plan for the corrective measures. Hence in the present investigation an attempt was made to record the clinical features of fluorotic patients in Basavan-Bagewadi and Muddebihal taluka of Bijapur district, Karnataka.

\section{Experimental}

The study was conducted in ten endemic villages of Basavan-Bagewadi taluka and eleven villages of Muddebihal taluka of Bijapur district. A sample survey was made after examination for dental, skeletal, joint pains and gastrointestinal diseases of both sexes between the ages of 8-50 years. The permanent teeth were the only once examined. The examinations were carried out by one dentist to standardize the readings. The Jackson index method of dental fluorosis was used. There are no major surface water sources in the study area however, main sources of drinking water in selected area are open wells, hand pumps and bore wells.

\section{Sample analysis}

A total of 28 samples from the villages of Basavan-Bagewadi taluka and 38 samples from the villages of Muddebihal taluka water sources were collected in polythene bottles, which were cleaned and finally washed with acid water, followed by rinsing twice with distilled water. The water samples collected were chemically analyzed. The analysis of water was done using procedure of standard methods ${ }^{12}$. Fluoride concentration was determined spectrophotometrically using Alizarin red-S and SPADNS reagents. The Alizarin red-S method was found useful in higher fluoride range while SPADNS reagent was employed in low fluoride range ${ }^{13}$.

\section{Results and Discussion}

The findings of the present investigation are summarized in Tables 1 and 2 were also made with WHO drinking water standards ${ }^{14}$.

In the present study electrical conductivity values of the samples were found to be 0.80 to 4.62 and 1.19 to $9.48 \mathrm{mhos} / \mathrm{cm}$. It shows that most of the samples were within the permissible limits (7.50-20.00 mhos $/ \mathrm{cm})$. However it is indicating high mineralization in that area. The $\mathrm{pH}$ value of study area ranges from 7.20 - 8.30 and 7.31- 8.5 and it is found to be well within the permissible limits prescribed for drinking water standards 9.65 - 8.5 (WHO 1970). The research finding revealed for TDS values ranging between $505-3424 \mathrm{mg} / \mathrm{L}$ and $3552-4117 \mathrm{mg} / \mathrm{L}$ respectively at Basavan-Bagewadi and Muddebihal taluka respectively. 
Table1. Physicochemical characteristics of water quality in selected villages of BasavanBagewadi taluka.

\begin{tabular}{|c|c|c|c|c|c|c|c|c|c|c|}
\hline S No. & Village & Source & $\begin{array}{c}\text { Cond, } \\
\mathrm{mho} / \\
\mathrm{cm}\end{array}$ & $\mathrm{pH}$ & $\begin{array}{l}\text { TDS, } \\
\mathrm{mg} / \mathrm{L}\end{array}$ & $\begin{array}{c}\text { Total } \\
\text { Hardness, } \\
\text { mg/L }\end{array}$ & $\begin{array}{c}\mathrm{Ca}, \\
\mathrm{mg} / \mathrm{L}\end{array}$ & $\begin{array}{c}\mathrm{Cl}, \\
\mathrm{mg} / \mathrm{L}\end{array}$ & $\begin{array}{l}\mathrm{SO}_{4} \\
\mathrm{mg} / \mathrm{L}\end{array}$ & $\begin{array}{c}\text { Fluoride } \\
\mathrm{mg} / \mathrm{L}\end{array}$ \\
\hline 1 & Karishyal & & & 8.03 & 814.00 & 572.00 & 29.00 & 58.00 & 148.00 & 640 \\
\hline 2 & Abbihal & $\mathrm{HP}$ & 1.40 & 7.8 & & 589.00 & & & 195.00 & 2.80 \\
\hline 3 & Vandal & $\mathrm{BW}$ & 2.80 & 8.10 & 1265 & 598.00 & 29.00 & 110.00 & 245.00 & \\
\hline 4 & Gonal(RC) & BW & 1.92 & 7.80 & 1362 & 600.00 & 32.00 & 130.00 & 310.00 & 6.40 \\
\hline 5 & Kadc & & 1.15 & 8.22 & & 560. & & 90 & 120.00 & 50 \\
\hline 6 & & & 2.12 & 7.80 & & 880.00 & & & 564.00 & \\
\hline 7 & $\begin{array}{l}\text { Maradagi } \\
\text { L.T (RC) }\end{array}$ & W & 3.60 & 8.00 & 2410.00 & 220.00 & 260.00 & 26000 & 1290.00 & \\
\hline 8 & Gani L T & BW & 1.00 & 7.50 & & 440.00 & & & 142.00 & 2.60 \\
\hline 9 & Aresh & B & 1.20 & 1.20 & 480 & 480.00 & 14.60 & 35.00 & 110.00 & 6.00 \\
\hline 10 & Mud & BW & 4.60 & 7.50 & 3424 & 600.00 & 120.00 & 660.00 & 1280.00 & 5.40 \\
\hline 11 & $\operatorname{Sin}$ & OW & 1.90 & 8.30 & & 950.00 & & & 544.00 & .40 \\
\hline 12 & Nan & BW & 2.03 & 7.40 & & 870.00 & 183 & & 325.00 & 70 \\
\hline 13 & Yara & & 4.62 & 7.50 & & 2380.00 & 675.00 & 1058.00 & 590.00 & 1.20 \\
\hline 14 & Hatt & & 2.10 & 7.67 & & 850.00 & & & 596.00 & 1.00 \\
\hline 15 & Raja & BW & 1.14 & 8.00 & & 460 & & 84. & 45.00 & 2.60 \\
\hline 16 & & BW & 2.00 & 8.10 & & 725.00 & 75.00 & 270.00 & 205.00 & 1.50 \\
\hline 17 & Hon & $\mathrm{BV}$ & 1.60 & 7.50 & & 685.00 & & 55.00 & 8.00 & 0.60 \\
\hline 18 & Ran & BW & 4.40 & 7.50 & & 845.00 & & 360 & 897.00 & 0.90 \\
\hline 19 & Naga & & 1.80 & 7.25 & 1225 & 382.00 & 40.00 & 190.00 & 120.00 & 0.40 \\
\hline 20 & & BW & 3.60 & 7.70 & & 1200.00 & 40.10 & 264.00 & 528.00 & 0.40 \\
\hline 21 & $\mathrm{Mad}$ & & 2.30 & 7.39 & & 620.00 & 48.00 & 364.00 & 300.00 & 0.70 \\
\hline 22 & Ingn & BW & 2.80 & 7.40 & 2220 & 800.00 & 64.12 & 630.00 & 425.00 & 0.50 \\
\hline 23 & & & 1.70 & 7.48 & & 1040.00 & $27 \varepsilon$ & & 180.00 & 0.60 \\
\hline 24 & & & 1.40 & 7.61 & 950 & 704.00 & 123.00 & 176. & 188.00 & 1.40 \\
\hline 25 & & BW & 1.70 & 7.50 & 1150.00 & 952.00 & 169.00 & 204.00 & 552.00 & 1.38 \\
\hline 26 & Mukartial & BW & 1.35 & 7.66 & & 536.00 & 56.00 & 100.00 & 168.00 & 1.80 \\
\hline 27 & & BW & 0.80 & 7.67 & & 456.00 & 47.00 & 72.00 & 44.00 & 2.00 \\
\hline 28 & Solawadagi & BW & 2.37 & 7.64 & 1584.00 & 596.00 & 41.00 & 220.00 & 472.00 & 1.20 \\
\hline
\end{tabular}

BW: Bore well $\quad$ HP: Hand pump OW: Open well

The analytical report reveals for total hardness concentration generally vary from 220-2380 and $160-3520 \mathrm{mg} / \mathrm{L}$. The samples were found to be more than the desired limit of 300-600 mg/L as prescribed by WHO. Present investigation data states that for calcium values ranges from 14675 and $16-454 \mathrm{mg} / \mathrm{L}$ and it indicates that the concentration were found to be more than the permissible limit prescribed for WHO (1970) drinking water quality standards. It is proved from the present research investigation report for chloride values ranges between $35-1058 \mathrm{mg} / \mathrm{L}$ and $31-1280 \mathrm{mg} / \mathrm{L}$, the prescribed drinking water standards for chloride is $200-600 \mathrm{mg} / \mathrm{L}$. The samples were found to be above the permissible limits of WHO (1970) prescribed drinking water standards. Sulphate values were from $8-1290 \mathrm{mg} / \mathrm{L}$ and $15-1632 \mathrm{mg} / \mathrm{L}$. These values were above the permissible limits of drinking water standards. Fluoride values vary from 0.40-6.40 mg/L and 1.10-7.10 mg/L. However 12 samples were within the range while 16 samples were above the permissible limits at Basavan-Bagewadi taluka where as in Muddebihal taluka all the values are above the permissible limits of WHO respectively. 
Table 2. Physicochemical characteristics of water quality in selected villages of Muddebihal taluka.

\begin{tabular}{|c|c|c|c|c|c|c|c|c|c|c|}
\hline S No. & Village & Source & $\begin{array}{c}\text { Cond, } \\
\mathrm{mho} / \\
\mathrm{cm}\end{array}$ & $\mathrm{pH}$ & $\begin{array}{l}\text { TDS, } \\
\mathrm{mg} / \mathrm{L}\end{array}$ & $\begin{array}{c}\text { Total } \\
\text { Hardness, } \\
\text { mg/L }\end{array}$ & $\begin{array}{c}\mathrm{Ca}, \\
\mathrm{mg} / \mathrm{L}\end{array}$ & $\begin{array}{c}\mathrm{Cl}, \\
\mathrm{mg} / \\
\mathrm{L}\end{array}$ & $\begin{array}{l}\mathrm{SO}_{4} \\
\mathrm{mg} / \mathrm{L}\end{array}$ & $\begin{array}{c}\text { Fluoride, } \\
\mathrm{mg} / \mathrm{L}\end{array}$ \\
\hline 1 & $\begin{array}{l}\text { Adavisomanal } \\
\text { infront } \\
\text { of pujari house }\end{array}$ & BW & 2.10 & 7.5 & 544 & 896 & 1181.0 & 304 & 536.00 & 3.20 \\
\hline 2 & $\begin{array}{l}\text { Hulagabal/Infront of } \\
\text { hanuman temple }\end{array}$ & BW & 3.33 & 7.5 & 2450 & 364 & 112.0 & 460 & 544.00 & 2.80 \\
\hline 3 & $\begin{array}{l}\text { Khilarahatti/Nr } \\
\text { Huligemma temple }\end{array}$ & OW & 1.19 & 7.8 & 844 & 352 & 48.0 & 120 & 116.0 & 3.60 \\
\hline 4 & $\begin{array}{l}\text { Garasangi } / \mathrm{Nr} \\
\text { basapa myageri field }\end{array}$ & BW & 1.76 & 8.5 & 1001 & 216 & 40.0 & 104 & 280.0 & 6.60 \\
\hline 5 & $\begin{array}{l}\text { Madri R C /Nr } \\
\text { Siddappa meti field }\end{array}$ & BW & 1.34 & 8.42 & 934 & 336 & 59.0 & 168 & 152.00 & 2.80 \\
\hline 6 & $\begin{array}{l}\text { Handral /Infront of } \\
\text { B Y Bidiri house }\end{array}$ & OW & 1.76 & 8.50 & 1276 & 160 & 16.0 & 132 & 304.0 & 5.80 \\
\hline 7 & $\begin{array}{l}\text { Kuchabal/Infront of } \\
\text { Hadapad master } \\
\text { Kuchabal/ Nr }\end{array}$ & BW & 1.78 & 7.31 & 1420 & 380 & 80.0 & 240 & 644.0 & 4.00 \\
\hline 8 & $\begin{array}{l}\text { Bhimashankar } \\
\text { temple }\end{array}$ & OW & 2.74 & 8.09 & 2100 & 600 & 126.0 & 420 & 848.0 & 2.80 \\
\hline 9 & $\begin{array}{l}\text { Lingadahalli/Infront } \\
\text { of M K Harijan }\end{array}$ & BW & 2.70 & 8.19 & 2098 & 628 & 50.0 & 252 & $\begin{array}{c}1024.0 \\
0\end{array}$ & 4.50 \\
\hline 10 & $\begin{array}{l}\text { Lingadahalli/Beside } \\
\text { hanuman temple }\end{array}$ & BW & 3.90 & 8.28 & 3020 & 544 & 43.0 & 480 & 1408.0 & 3.30 \\
\hline 11 & $\begin{array}{l}\text { Bantanur (Tanda)/ } \\
\text { Nr Kulkarni pond } \\
\text { Gutakhandaki }\end{array}$ & OW & 1.10 & 8.36 & 766 & 204 & 29.0 & 52 & 128.0 & 3.10 \\
\hline 12 & $\begin{array}{l}\text { /Garasangapp } \\
\text { Gowda kannal }\end{array}$ & BW & 7.16 & 7.76 & 498 & 232 & 38.0 & 32 & 24.0 & 3.30 \\
\hline 13 & $\begin{array}{l}\text { Geddalamari / } \mathrm{Nr} \\
\text { Bus stand }\end{array}$ & BW & 9.48 & 7.67 & 544 & 372 & 54.0 & 80 & 32.0 & 1.60 \\
\hline 14 & $\begin{array}{l}\text { Hadalageri /Infront } \\
\text { of Durganna temple }\end{array}$ & OW & 4.98 & 7.48 & 3490 & 1520 & 186.0 & 1072 & 464.0 & 3.10 \\
\hline 15 & $\begin{array}{l}\text { Mudnal LT.2/In } \\
\text { Tanda }\end{array}$ & BW & 8.38 & 8.09 & 618 & 380 & 56.0 & 72 & 52.0 & 2.50 \\
\hline 16 & $\begin{array}{l}\text { Budihal } \\
\text { (PN)/Mallappa } \\
\text { Koganur } \\
\text { Budihal PN)/ }\end{array}$ & BW & 8.66 & 7.44 & 626 & 336 & 73.5 & 72 & 38.0 & 2.80 \\
\hline 17 & $\begin{array}{l}\text { Behind anganawadi } \\
\text { Kendra } \\
\text { Jangamural/Nr }\end{array}$ & BW & 7.14 & 7.30 & 546 & 304 & 65.5 & 40 & 24.0 & 3.0 \\
\hline 18 & $\begin{array}{l}\text { Govt. Primary } \\
\text { School }\end{array}$ & BW & 1.86 & 7.53 & 1260 & 280 & 46.0 & 128 & 320.0 & 4.20 \\
\hline
\end{tabular}




\begin{tabular}{|c|c|c|c|c|c|c|c|c|c|c|}
\hline & Malagaladinni / & & & & & & & & & \\
\hline 19 & $\begin{array}{l}\text { Infront of } \\
\text { Hanumant Somanal } \\
\text { house }\end{array}$ & BW & 1.86 & 7.45 & 1360 & 444 & 89.5 & 220 & 240.0 & 2.50 \\
\hline 20 & $\begin{array}{l}\text { HULLUR LT-1/Nr } \\
\text { Basu Rathod house }\end{array}$ & BW & 6.75 & 7.88 & 460 & 416 & 38.0 & 32 & 17.0 & 6.40 \\
\hline 21 & $\begin{array}{l}\text { Jattagi /Nr Overhead } \\
\text { water tank }\end{array}$ & OW & 8.57 & 8.09 & 594 & 224 & 35.0 & 44 & 15.0 & 4.60 \\
\hline 22 & $\begin{array}{l}\text { Koppal / In } \\
\text { Shanteshwar Math } \\
\text { Ingalgeriokkp }\end{array}$ & BW & 6.47 & 7.78 & 426 & 208 & 48.0 & 24 & 18.50 & 7.10 \\
\hline 23 & $\begin{array}{l}\text { Ingalageri /At Bus } \\
\text { stop }\end{array}$ & BW & 5.52 & 7.56 & 4117 & 3520 & 454.0 & 1280 & 16320 & 2.60 \\
\hline 24 & $\begin{array}{l}\text { Chilmi /Nr kandoni } \\
\text { house }\end{array}$ & BW & 1.26 & 7.79 & 768 & 400 & 53.0 & 92 & 74.0 & 5.30 \\
\hline 25 & $\begin{array}{l}\text { Kalagi /Nr Govt. } \\
\text { Hospital }\end{array}$ & BW & 1.32 & 8.20 & 830 & 248 & 50.0 & 176 & 160.0 & 6.50 \\
\hline 26 & $\begin{array}{l}\text { Gonal (S.H.)/Nr } \\
\text { Siddappa } \\
\text { Chalavadi's house }\end{array}$ & BW & 3.43 & 7.08 & 2510 & 1088 & 145.5 & 520 & 1152.0 & 2.90 \\
\hline 27 & $\begin{array}{l}\text { Sarur }(\mathrm{LT}) / \mathrm{Nr} \\
\text { D.P.Pandeppa Field }\end{array}$ & BW & 8.52 & 7.46 & 670 & 304 & 62.0 & 72 & 23.0 & 4.80 \\
\hline 28 & $\begin{array}{l}\text { Bellur/Nr V.J. } \\
\text { Deshmukh Field }\end{array}$ & BW & 4.84 & 8.11 & 352 & 256 & 54.0 & 31 & 93.0 & 1.10 \\
\hline 29 & $\begin{array}{l}\text { Gadisomnal(LT)/ } \\
\text { infront of Shivalay } \\
\text { temple }\end{array}$ & BW & 6.88 & 8.61 & 490 & 68 & 11.0 & 32 & 13.0 & 3.50 \\
\hline 30 & $\begin{array}{l}\text { Kolur /On Kolur } \\
\text { tanda ways } \\
\text { Madikeshwar }\end{array}$ & MWS & 2.17 & 8.13 & 1606 & 412 & 81.5 & 204 & 480.0 & 6.20 \\
\hline 31 & $\begin{array}{l}\text { Gudihal /Infront of } \\
\text { primory school }\end{array}$ & BW & 2.33 & 7.70 & 1642 & 416 & 40.0 & 184 & 608.0 & 3.40 \\
\hline 32 & $\begin{array}{l}\text { Gudihal /Nr } \\
\text { M.N.Nadaf house }\end{array}$ & BW & 2.02 & 7.63 & 1412 & 332 & 64.0 & 200 & 528.0 & 5.30 \\
\hline 33 & $\begin{array}{l}\text { Minijigi /At } \\
\text { Ashraya colony }\end{array}$ & BW & 1.99 & 7.33 & 1472 & 632 & 134.0 & 240 & 600.0 & 5.50 \\
\hline 34 & $\begin{array}{l}\text { Shivapur /Open } \\
\text { well outside the } \\
\text { village }\end{array}$ & OW & 1.90 & 8.0 & 1482 & 548 & 99.0 & 348 & 316.0 & 2.40 \\
\hline 35 & $\begin{array}{l}\text { Jainapur /Infront of } \\
\text { Primory school } \\
\text { Amaragol /Inside }\end{array}$ & BW & 8.07 & 7.74 & 554 & 268 & 45.0 & 56 & 38.0 & 3.30 \\
\hline 36 & the janata plot & BW & 1.59 & 8.24 & 1094 & 324 & 59.0 & 156 & 232.0 & 2.60 \\
\hline 37 & $\begin{array}{l}\text { Bhilebhavi / Nr } \\
\text { Dyavappa Met field }\end{array}$ & BW & 8.60 & 8.05 & 600 & 228 & 46.0 & 68 & 76.0 & 4.10 \\
\hline 38 & $\begin{array}{l}\text { Nalatawad } / \mathrm{Nr} \\
\text { Basaveshwar high } \\
\text { schhol }\end{array}$ & BW & 1.66 & 7.56 & 1180 & 264 & 49.5 & 120 & 464.0 & 4.20 \\
\hline
\end{tabular}


It is evident from the analysis data; it is obvious that the fluoride concentration is more than the limits for drinking purpose. Fluoride content of $1 \mathrm{mg} / \mathrm{L}$ in drinking water has no biological side effects ${ }^{15}$. Studies in these areas revealed that fluoride level is more than the permissible limit in the drinking water and consumed for a period of 5-10 years caused dental fluorosis. Between 4-8 mg/L for a period 15-20 years caused severe form of dental and mild form of skeletal fluorosis and if it exceeded $8 \mathrm{mg} / \mathrm{L}$ and consumed for 5-10 years or more caused severe form of dental and skeletal fluorosis. Therefore, drinking water is sufficient to produce severe form of dental and mild form of skeletal fluorosis consumed for a period of 1520 years ${ }^{16}$. Clinical symptoms of dental and sketetal fluorosis in Gadag and Bagalkot districts of Karnataka is reported ${ }^{17}$. Health status of the people is varied in different villages because of severity of fluorosis, which is direct reflection of fluoride content of drinking water.

The Clinical symptoms of fluorotic patients from Basavan-Bagewadi and Muddebihal taluka at various age groups are presented in Table 3 and 4 respectively. The table demonstrates the fluorosis in the age group and clearly shows the prevalence of more advanced fluorosis, joint pains, gastrointestinal discomfort and excessive thirst in the older age groups. The result shows that 824 (25.89\%) people of 2992 examined had dental and skeletal fluorosis, 302 (10.82\%) joint pains, $326(10.89 \%)$ gastrointestinal diseases at different stages at Basavan-Bagewadi taluka.

Table 3. The Clinical symptoms of fluorotic patients from Basavan-Bagewadi taluka.

\begin{tabular}{|c|c|c|c|c|c|c|c|}
\hline 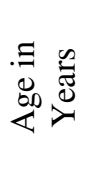 & $\begin{array}{l}\text { No. of } \\
\text { peoples } \\
\text { examined }\end{array}$ & $\begin{array}{l}\text { No. of peoples } \\
\text { with dental and } \\
\text { skeletal } \\
\text { fluorosis }\end{array}$ & 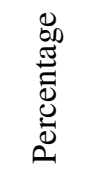 & $\begin{array}{l}\text { No. of peoples } \\
\text { suffering from } \\
\text { joint pain }\end{array}$ & 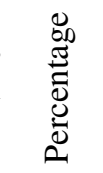 & $\begin{array}{l}\text { No. of peoples } \\
\text { with } \\
\text { gastrointestinal } \\
\text { discomfort }\end{array}$ & 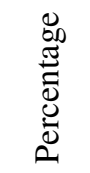 \\
\hline $8-16$ & 697 & 109 & 15.63 & 82 & 11.88 & 155 & 22.23 \\
\hline $17-25$ & 1070 & 312 & 29.15 & 91 & 8.50 & 64 & 5.98 \\
\hline $26-50$ & 1225 & 403 & 32.89 & 129 & 10.53 & 107 & 8.73 \\
\hline
\end{tabular}

Table 4. The Clinical symptoms of fluorotic patients from Muddebihal taluka.

\begin{tabular}{|c|c|c|c|c|c|c|c|}
\hline 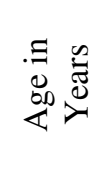 & $\begin{array}{c}\text { No. of } \\
\text { peoples } \\
\text { examined }\end{array}$ & $\begin{array}{l}\text { No. of peoples } \\
\text { with dental } \\
\text { and skeletal } \\
\text { fluorosis }\end{array}$ & 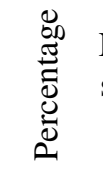 & $\begin{array}{l}\text { No. of peoples } \\
\text { suffering from } \\
\text { joint pain }\end{array}$ & 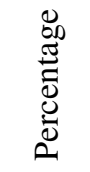 & $\begin{array}{l}\text { No. of peoples } \\
\text { with } \\
\text { gastrointestinal } \\
\text { discomfort }\end{array}$ & 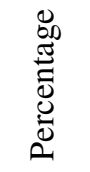 \\
\hline $8-16$ & 845 & 175 & 20.71 & 82 & 8.16 & 123 & 14.55 \\
\hline $17-25$ & 733 & 230 & 31.37 & 82 & 11.18 & 107 & 14.59 \\
\hline $26-50$ & 1118 & 407 & 36.40 & 173 & 15.47 & 185 & 16.54 \\
\hline
\end{tabular}

Out of 2696 people 812 (29.49\%) skeletal and dental fluorosis, 347 (12.87\%) joint pains, $415(15.39 \%)$ gastrointestinal disease at Muddebihal taluka respectively. Lack of luster was the most common symptoms of dental fluorosis experienced by the subjects of Basavan-Bagewadi and Muddebihal taluka followed by browning of teeth. The dental fluorosis, joint pains and gastrointestinal diseases was more severe in Muddebihal taluka, which can be attributed to the differences in fluoride content of water in these two areas. Fluoride content of drinking water of Mundaragi taluka ranged from 4.00-10.5 $\mathrm{ppm}^{18}$. While that of Hunagund taluka ranged from 2.04-3.2 $\mathrm{ppm}^{19}$. The various grade of discoloration of teeth ranging from chalky white to yellow or brown with pitting. This difference being attributed to fluoride content of drinking water, poor nutritional and economic status in addition to the consumption of locally grown foods. The difference in fluoride content of water, intake of fluoride, temperature are the major factors responsible for the accumulation of higher fluoride leading to increased severity of the diseases ${ }^{20}$. 


\section{Conclusion}

From the result and discussion presented above the important role of drinking water in the incidence of fluorosis is obvious. It is therefore, essential that the villages affected by fluorosis be supplied with safe drinking water less than $1 \mathrm{mg} / \mathrm{L}$ fluoride, either by changing the water source to safer once or by adapting suitable treatment technique to remove fluoride in the existing sources. Since grains, vegetables and milk are also significant sources of fluoride to man, their fluoride content could be taken into account while fixing the safe level of fluoride in drinking water.

\section{References}

1. $\quad$ Preek R, The Indian J Nutr Diet., 1994, 31,121-125.

2. Environmental health criteria for fluorine and fluorides, Geneva; WHO, 1984, 1-136.

3. Carlson.C H, Armstrong W D and Singer L, Distribution and excretion of radiofluoride in the human.Proc Soc Exper Biol Med.,(NY), 1960, 104, 235-239.

4. Jacyzynx and Marut A, Fluoride, 1986, 19(1), 26-32.

5. Puspha Bharati, Annapurna, Kubakaddi, Meera Rao and Rama K Naik, J Hum Ecol., 2005, 18(2),105-107.

6. $\quad$ Krishnamachari, KAVR, Indian J Med Res., 1976, 64(2); 284-291.

7. Pandit C G, Raghavachari J N S, Rao D S and Krishnamurthi V, Indian J Med Res., 1940, 28, 533-35.

8. Satyanarayan, Maruti G V, Rao D N and Venkateshwaralu P, J Indian Med Assoc., 1953, 22, 396.

9. Siddiqui A H, Br Med J., 1955, 2, 1408-1413.

10. Nawlakha W G and Paramsivam R, Curr Sci., 1993, 65(10), 743-748

11. Susheela A K, Curr Sci., 1999, 77(10), 1250-1256.

12. Standard methods for the examination of water and waste water (18 Edn) American Public Health Association, New York, 1995.

13. Gupta S C, Rathore G S and Doshi.C S, Indian J Environ Health, 1993, 35(2), 97-109.

14. WHO,Fluoride and Human health Monograph Series No. 59, World Health Organization, Geneva, 1970.

15. Leone N C, Public Health Rep., 1954, 69, 925.

16. Galagon D T and Lamson G G, Public Health Rep., 1953, 68, 497-508.

17. Pushpa Bharati, Annapurna Kubakaddi, Meera Rao and Rama.K.Naik, J Hum Ecol., 2005, 18(2), 105-107.

18. Bharati P and Rao Meera, J Hum Ecol., 2001, 14(1), 37-42.

19. Kubakaddi A B, Epidemiology of fluorosis and Educational Intervention in Hunagund Taluka, M.H Sc. Thesis, University of Agricultural Sciences, Dharawad, 2001.

20. Choubisa.S L, Sampura K, Choubisa P K and sharma.O.P, Indian J Environ Health, 1996, 38, 286-292. 


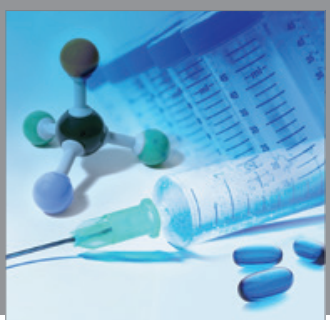

International Journal of

Medicinal Chemistry

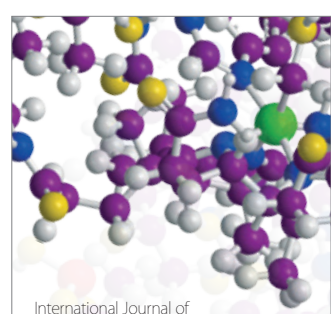

Carbohydrate Chemistry

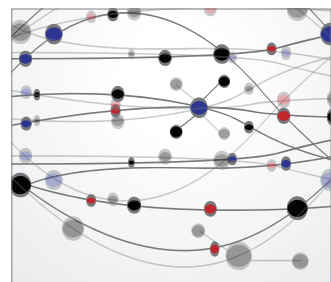

The Scientific World Journal
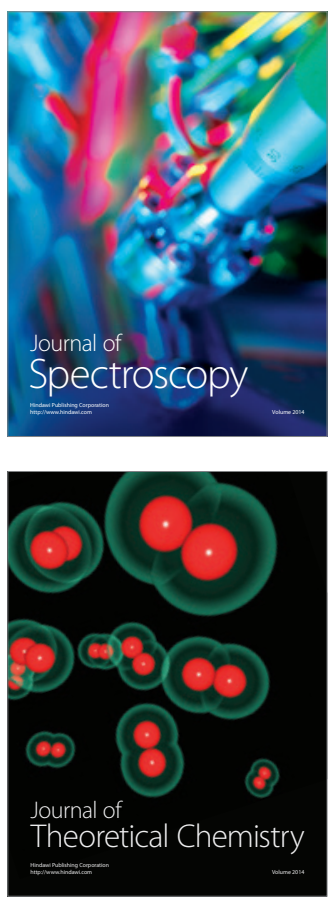
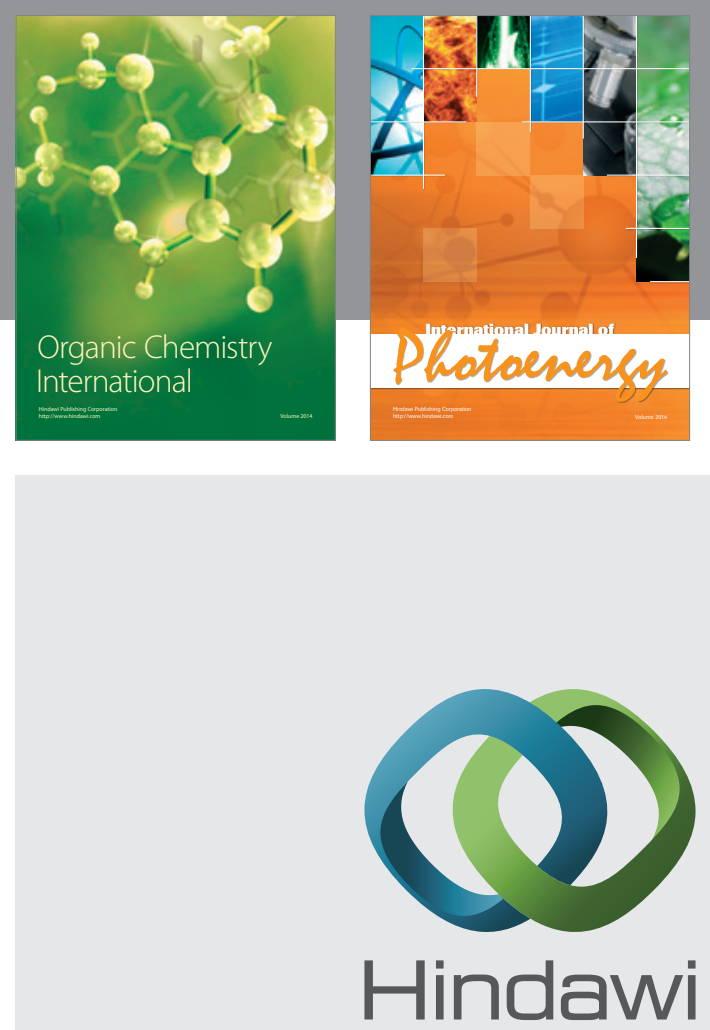

Submit your manuscripts at

http://www.hindawi.com
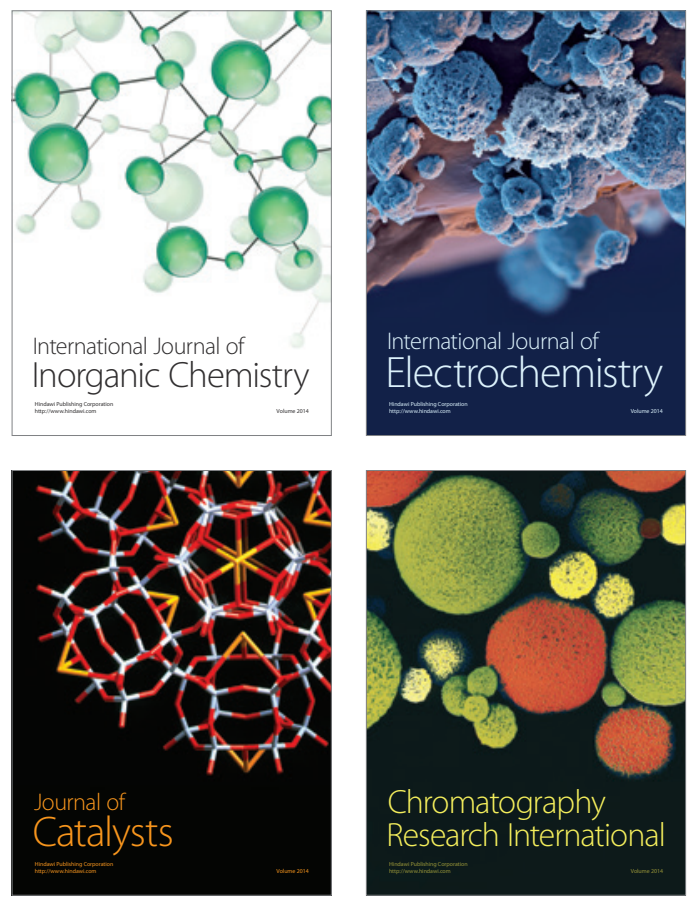
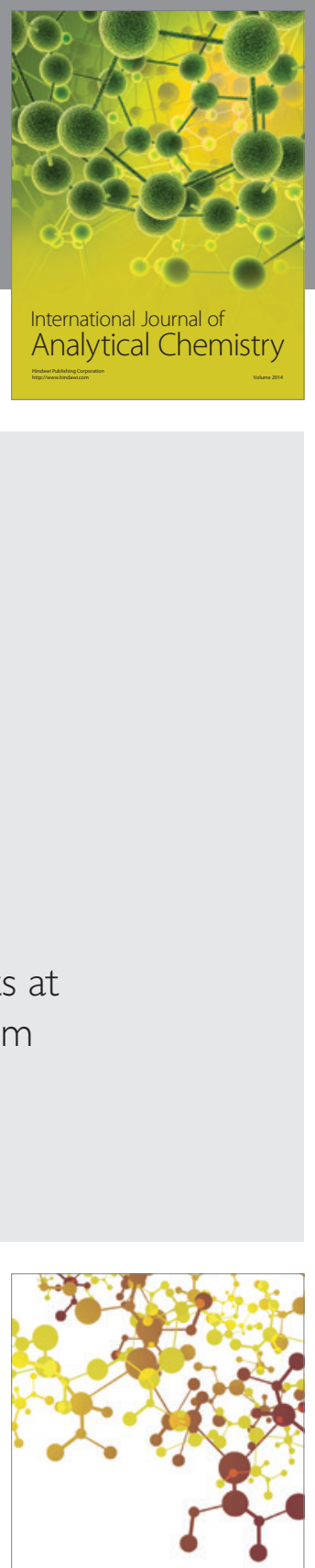

Journal of

Applied Chemistry
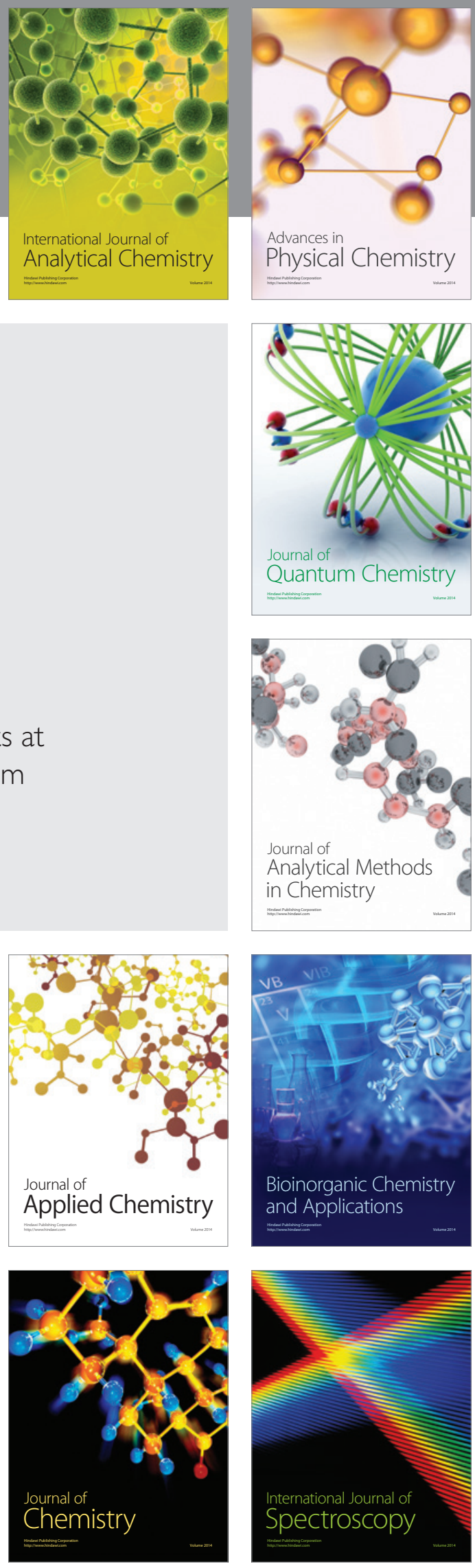